Acta vet. scand. $1972,13,269-271$.

Brief Communication

\title{
AMNIOTIC AND ALLANTOIC FLUID LEVELS OF OESTROGENS AT DIFFERENT STAGES OF DEVELOPMENT IN THE GOAT*
}

During our studies on certain aspects of reproduction in the goat (Lyngset 1971) we collected several samples of foetal fluid which were stored in the frozen state for further investigation. We have now processed this material with respect to contents of oestrogens.

Preliminary analyses indicated that the foetal fluids contained oestradiol-17 $\alpha$ as well as oestrone and that both steroids were present mostly as water soluble conjugates. For the quantitative analyses subsequently performed samples of the foetal fluid $(10 \mathrm{ml})$ were diluted with water $(10 \mathrm{ml})$ and admixed with ammonium sulphate $(10 \mathrm{~g})$. The conjugates were then extracted with acetone $(20 \mathrm{ml})$. After evaporation of the acetone the aquous residue of the extract was adjusted to $10 \mathrm{ml}$ with water and refluxed with $\mathrm{HCl}$ (conc., $1.5 \mathrm{ml}$ ) under toluene $(20 \mathrm{ml}$ ) for $1 \mathrm{hr}$. The conjugate extraction step had been developed during a study on porcine foetal fluids for which it improved the yield of oestrogens as well as the precision of the analyses.

Chromatography of a phenolic fraction after methylation was performed on alumina columns to separate oestrone from oestradiols (Brown 1955). Fluorimetry (Lunaas 1964) was applied for quantification of oestrogens in suitable aliquots of the eluates.

The appearance of oestrogens (Table 1 ) in the foetal fluids at the early stages presumably reflects oestrogen production in the placenta which gives rise to urinary excretion of oestrone and oestradiol-17 $\propto$ from Day 30-50 after conception (Van Rensburg 1971). It is interesting to note that the onset of the oestrogen production appears to coincide in time with a rapid expansion of the foetal fluid compartments.

* The investigation was financially supported by the Agricultural Research Council of Norway and Statens Veterinærvitenskapelige Forskningsfond. 
T a b l e 1. Foetal fluid contents of oestrone $\left(\mathrm{Oe}_{1}\right)$ and oestradiol-17 $\alpha$ $\left(\mathrm{Oe}_{2}\right)$ in the goat.

\begin{tabular}{|c|c|c|c|c|c|c|}
\hline \multirow[t]{2}{*}{$\begin{array}{l}\text { Day of } \\
\text { pregnancy }\end{array}$} & \multicolumn{2}{|c|}{$\begin{array}{l}\text { Volume of foetal } \\
\text { fluids }(\mathbf{m l})\end{array}$} & \multicolumn{2}{|c|}{$\begin{array}{l}\text { Sum total } \mathrm{Oe}_{1}+\mathrm{Oe}_{2} \\
(\mu \mathrm{g} / 100 \mathrm{ml})\end{array}$} & \multicolumn{2}{|c|}{$\mathrm{Oe}_{2} \%$ of total } \\
\hline & amn. & all. & amn. & all. & amn. & all. \\
\hline 26 & 2 & 39 & - & 0.02 & & \\
\hline 31 & 5 & 10 & - & 0.16 & & \\
\hline 45 & 92 & 340 & 2.4 & 0.7 & 47.8 & 28.6 \\
\hline 60 & 100 & 210 & 60.2 & 31.4 & 34.6 & 42.7 \\
\hline 60 & 370 & 400 & 93.2 & 21.2 & 55.7 & 55.2 \\
\hline 75 & 360 & 260 & 206.7 & 83.2 & 55.9 & 58.1 \\
\hline 75 & 200 & 500 & 190.6 & 78.3 & 62.9 & 61.7 \\
\hline 90 & 530 & 230 & 346.1 & 110.4 & 92.5 & 96.6 \\
\hline 90 & 700 & 325 & 178.9 & 70.3 & 93.5 & 79.9 \\
\hline 105 & 480 & 680 & 30.1 & 48.0 & 96.0 & 86.9 \\
\hline 105 & 290 & 240 & 207.1 & 64.5 & 96.8 & 95.3 \\
\hline 120 & 300 & 760 & 2.1 & 79.8 & 100.0 & 97.0 \\
\hline 120 & 330 & 740 & 1.7 & 77.1 & 88.2 & 93.8 \\
\hline 130 & 200 & 350 & 40.1 & 142.3 & 97.0 & 91.8 \\
\hline 140 & 1025 & 670 & 15.7 & 276.6 & 92.9 & 92.6 \\
\hline 145 & 630 & 800 & 19.2 & 154.3 & 97.4 & 92.7 \\
\hline
\end{tabular}

During mid-pregnancy the amniotic fluid contained much more oestrogens than did the allantoic fluid but this relationship was later reversed.

Normally the oestrogen production in the pregnant goat is rather modest until about Day 100 after which time, as judged from the urinary excretion (Van Rensburg), it increases greatly towards parturition. The latter trend was to some degree apparent in the allantoic fluid levels of oestrogens, but certainly not in the amniotic fluid in which the contents after about Day 100 decreased rather than increased towards parturition.

The finding of relatively small amounts of oestrogens in the amniotic compartment during the late stages could be taken to indicate that its fluid may then be exchanged without import of oestrogens and that the foetal urine, which presumably might contain oestrogens, is disposed of largely by the urachus route into the allantoic cavity. Another possible explanation would be that the foetus at advanced stages of development may engulf the fluid in which it is bathed (Speert 1943) and that the oestrogens to a large extent are thereby transferred to the foetus itself. This possibility is supported by the fact that caprine meconium is exceptionally rich in oestradiol-17 $\alpha$ (Velle 1963). 
Considering the number of compartments and tissues involved it is obvious that the dynamics of oestrogen production, transport and metabolism in the conceptus must be very complex. As to production and metabolism the data presented here clearly indicate that the ratio oestradiol-17 $\alpha$ to oestrone in the allantoic as well as in the amniotic fluid increases markedly during the third month of development. A similar change seems to occur in the urinary ratio between these oestrogens during this stage (Van Rensburg).

\section{Olav Lyngset and Torleiv Lunaas}

The Division of Postgraduate and Continuing Education, The Department of Reproductive Physiology and Pathology, Veterinary College of Norway, Oslo.

\section{REFERENCES}

Brown, J. B.: A chemical method for the determination of oestriol, oestrone and oestradiol in human urine. Biochem. J. 1955, 60, 185-193.

Lunaas, T.: Spectrophotometric methods for the analysis of mixtures of oestradiol-17 $\alpha$ and oestradiol-17 $\beta$. Acta chem. scand. 1964, $18,321-328$.

Lyngset, 0. : Studies on reproduction in the goat. VII. Pregnancy and the development of the foetus and the foetal accessories of the goat. Acta vet. scand. 1971, 12, 185-201.

Speert, H.: Swallowing and gastrointestinal activity in the fetal monkey. Amer. J. Obstet. Gynecol. 1943, 45, 69-82.

Van Rensburg, S. J.: Reproductive physiology and endocrinology of normal and habitually aborting angora goats. Onderstepoort $\mathrm{J}$. vet. Res. $1971,38,1-62$.

Velle, W.: Metabolism of estrogenic hormones in domestic animals. Gen. comp. Endocr. 1963, 3, 621-635.

(Received April 10, 1972).

Reprints may be requested from: T. Lunaas, Norges Veterinærh $\varnothing$ gskole, Postboks 8146, Oslo Dep., Oslo 1, Norge. 